\title{
PENGEMBANGAN MEDIA POSTER BERBASIS PENDIDIKAN KARAKTER UNTUK MATERI GLOBAL WARMING
}

\author{
Sri Maiyena \\ Program Studi Pendidikan Fisika, Jurusan Tarbiyah STAIN Batusangkar \\ Korespondensi: J1. Sudirman, No.137 Kubu Rajo, Lima Kaum, Batusangkar \\ E-mail: sri_maiyena@yahoo.com
}

\begin{abstract}
This research was done because of the students' difficulties in understanding the concept of global warming and implementing character values so that it needed to design poster media based character education. This research was aimed to see the effectiveness of poster media based character education that was already developed in Ilmu Alamiah Dasar subject. The design of the research was a research development. The effectiveness of poster media was gotten from testing to the students who had conducted Ilmu Alamiah Dasar subject. The instrument of the research was questionnaire. The result of the rsearch showed that developing poster media based character education was very effective according to the students with percentage $81.9 \%$.
\end{abstract}

Kata kunci: media poster berbasis pendidikan karakter, praktis, global warming

\section{PENDAHULUAN}

$\mathrm{P}$ endidikan merupakan usaha sadar dan terencana untuk mewujudkan suasana belajar dalam proses pembelajaran, agar peserta didik dapat secara aktif mengembangkan potensi dirinya untuk memiliki kekuatan spiritual. Untuk mewujudkan hal di atas, keseriusan dan kesungguhan dari berbagai pihak yang terkait dengan dunia pendidikan sangat dibutuhkan. Hal ini disebabkan karena dunia pendidikan dinilai mampu melahirkan lulusan manusia yang intelektualitas dan memiliki kepribadian yang baik.

Pada kenyataannya dalam kehidupan sehari-hari, banyak peserta didik melakukan tindakan yang tidak sesuai dengan nilai-nilai karakter, seperti tindakan merusak lingkungan, tawuran, dan melanggar disiplin di sekolah. Hal ini disebabkan oleh pendidikan cenderung diarahkan pada pembentukan kecerdasan intelektual tanpa diimbangi dengan pembentukan kecerdasan emosional yang tercermin pada nilai-nilai karakter.

Untuk mengatasi permasalahan di atas, pemerintah telah melakukan berbagai upaya dalam bidang pendidikan yang bertujuan untuk pengembangan dan pembinaan karakter. Upaya yang tersebut diantaranya penggunaan media pembelajaran, melengkapi sarana dan prasarana pendidikan serta meningkatkan kemampuan tenaga pendidik.

Dari beberapa komponen di atas, media pembelajaran merupakan salah satu tolak ukur keberhasilan pembelajaran. Nilai-nilai karakter dapat dikembangkan dan ditanamkan kepada peserta didik melalui proses pendidikan karakter. Salah satu bentuk media pembelajaran yang dapat digunakan adalah media poster. Media poster berfungsi sebagai media yang mengandung anjur- 
an atau larangan, dimana media poster ini terdiri dari lambang kata atau simbol yang sangat sederhana. Bila dilihat dari komponen di atas, media poster lebih dapat memaparkan nilai-nilai karakter yang akan dikembangkan dan ditanamkan kepada peserta didik, dimana nilainilai karakter yang akan ditanamkan dapat dicantumkan secara jelas pada poster itu sendiri.

Berdasarkan kondisi yang ada di lapangan saat ini, dapat dilihat pendidik belum memiliki media pembelajaran berbasis pendidikan karakter. Umumnya pendidik menggunakan media konvensional dan media yang di-download dari internet atau membeli $C D$ yang berisi media pembelajaran. Hal ini menyebabkan pendidik mengalami kendala dalam pengembangan media pembelajaran berbasis pendidikan karakter. Proses pengembangan dan penanaman nilai-nilai karakter pada materi global warming tidak terealisasi. Padahal untuk materi ini, pendidik dapat mengembangkan dan menanamkan beberapa nilai-nilai karakter. Salah satu contohnya, nilai karakter rasa ingin tahu, peduli terhadap lingkungan, bertanggung jawab, sosial yang dapat ditanamkan pada proses pembelajaran tersebut. Dengan kata lain, nilai karakter dapat ditanamkan kepada peserta didik dengan cara mengaitkan ilmu pengetahuan dengan kehidupan sehari-hari, sehingga hal tersebut akan mempermudah pendidik dalam mengembangkan dan menanamkan nilai-nilai karakter yang ingin dicapai.

Penggunaan media poster dalam pembelajaran pernah dilakukan oleh Kurniasih $^{3}$, dimana penggunaan poster siswa lebih mampu menulis puisi dibandingkan jika tidak menggunakan poster. Disamping itu, Kusuma ${ }^{4}$ juga pernah menggunakan media poster ini untuk meningkatkan kemampuan men- ceritakan kembali cerita anak secara lisan pada siswa kelas II SDN Pulungdowo 03 Tumpang Malang. Dari penelitian diperoleh hasil bahwa dengan menggunakan media poster dapat meningkatkan kemampuan siswa dalam menceritakan kembali cerita anak secara lisan.

Berdasarkan uraian di atas, maka peneliti tertarik untuk melakukan penelitian mengenai pengembangan Media poster berbasis pendidikan karakter untuk materi global warming. Tujuan penelitian ini adalah untuk melihat kepraktisan penggunaan media poster berbasis pendidikan karakter.

\section{KAJIAN TEORI}

\section{Pendidikan Karakter}

Karakter diartikan sebagai kebiasaan (habit) seperti kebiasaan dalam berpikir, kebiasaan dalam rasa dan kebiasaan dalam tingkah laku ${ }^{6}$. Karakter seseorang dipengaruhi oleh genetic dan lingkungan sekitar. Dari proses pembentukan karakter akan mempengaruhi cara individu tersebut memandang diri dan lingkungannya dan kemudian akan tercermin dalam prilakunya sehari-hari.

Dalam the six pillars of character yang dikeluarkan oleh Character Counts Coalition (a project of The Joseph Institute of Ethics) ${ }^{2}$. Enam jenis karakter yang dimaksud adalah:

1. Trustworthiness, bentuk karakter yang membuat seseorang menjadi: berintegritas, jujur dan loyal.

2. Fairness, bentuk karakter yang membuat seseorang memiliki pemikiran terbuka serta tidak suka memanfaatkan orang lain.

3. Caring, bentuk karakter yang membuat seseorang memiliki sikap peduli dan perhatian terhadap orang 
lain maupun kondisi sosial lingkungan sekitar.

4. Respect, bentuk karakter yang membuat seseorang selalu menghargai dan menghormati orang lain.

5. Citizenship, bentuk karakter yang membuat seseorang sadar hukum dan peraturan serta peduli terhadap lingkungan alam.

6. Responsibility, bentuk karakter yang membuat seseorang bertanggung jawab, disiplin, dan selalu melakukan sesuatu dengan sebaik mungkin.

\section{Media Pembelajaran}

Media berasal dari bahasa latin merupakan bentuk jamak dari "Medium" yang secara harfiah berarti "Perantara" atau "Pengantar" yaitu perantara atau pengantar sumber pesan dengan penerima pesan. Beberapa ahli memberikan definisi tentang media pembelajaran. Schramm ${ }^{1}$ mengemukakan bahwa media pembelajaran adalah teknologi pembawa pesan yang dapat dimanfaatkan untuk keperluan pembelajaran.

Sementara itu, Briggs ${ }^{1}$ berpendapat bahwa media pembelajaran adalah sarana fisik untuk menyampaikan isi atau materi pembelajaran seperti: buku, film, video dan sebagainya. Sedangkan, National Education Associaton ${ }^{l}$ mengungkapkan bahwa media pembelajaran adalah sarana komunikasi dalam bentuk cetak maupun pandang-dengar, termasuk teknologi perangkat keras. Dari ketiga pendapat di atas disimpulkan bahwa media pembelajaran adalah segala sesuatu yang dapat menyalurkan pesan, dapat merangsang fikiran, perasaan, dan kemauan peserta didik sehingga dapat mendorong terciptanya proses belajar pada diri peserta didik. Jadi, media pembelajaran adalah alat bantu guru untuk mengajar yang digunakan adalah alat bantu visual.

\section{Media Poster}

Poster adalah salah satu media yang terdiri dari lambang kata atau simbol yang sangat sederhana dan pada umumnya mengandung anjuran atau larangan ${ }^{1}$. Menurut Sudjana dan Rivai ${ }^{1}$ poster adalah sebagai kombinasi visual dari rancangan yang kuat, dengan warna, dan pesan dengan maksud untuk menangkap perhatian orang yang lewat tetapi cukup lama menanamkan gagasan yang berarti didalam ingatannya.

Poster disebut juga plakat, lukisan atau gambar yang dipasang telah mendapat perhatian yang cukup besar sebagai suatu media untuk menyampaikan informasi, saran, pesan dan kesan, ide dan sebagainya. Poster memiliki kelebihan, yaitu harganya terjangkau oleh seorang guru atau tenaga pengajar. Dalam media poster memvisualisasikan pesan, informasi atau konsep yang ingin disampaikan kepada siswa. Poster menghadirkan ilustrasi melalui gambar yang hampir menyamai kenyataan dari sesuatu objek atau situasi.

\section{Global Warming}

Global warming adalah suatu proses meningkatnya suhu rata-rata atmosfer, laut, dan daratan bumi. Peningkatan suhu udara secara global disebabkan karena terjadinya peningkatan konsentrasi gas rumah kaca $\left(\mathrm{CO}_{2}, \mathrm{CH}_{4}\right.$, $\mathrm{CFC}, \mathrm{NO}_{2}, \mathrm{SO}_{2}$ ) di atmosfir ${ }^{5}$. Konsentrasi $\mathrm{CO}_{2}$ diatmosfir merupakan persentase terbesar penyebab terjadinya global warming. Ia menyumbangkan lebih dari $60 \%$ dari total gas rumah $\mathrm{kaca}^{8}$. Persentase terbesar yang disumbangkan oleh $\mathrm{CO}_{2}$ disebabkan oleh kenaikan pembakaran bahan bakar minyak, batu bara dan bahan bakar organik lainnya.

$\mathrm{SO}_{2}, \mathrm{NO}_{2}$ pada umumnya dihasilkan oleh pengguna batu bara, minyak, kendaraan dan industri. Sedangkan emisi gas metana disebabkan 
oleh aktivitas industri dan pertanian. Karbon dioksida, Chlorofluorocarbon, metan, asam nitrat merupakan gas-gas polutif yang terakumulasi di udara dan menyaring banyak panas dari matahari.

Di samping itu konsumsi energi di dunia juga bertambah. Negara-negara maju mengonsumsi energi sekitar $70 \%$ dimana sekitar $78 \%$ dari energi tersebut berasal dari bahan bakar fosil ${ }^{7}$. Aktivitas manusia yang lain seperti penggundulan hutan akan mengurangi penyerapan karbon dioksida, sehingga terjadi pertambahan emisi karbon sebesar $20 \%$. Dampak selanjutnya dapat mengubah iklim mikro lokal dan siklus hidrologis dan akan berdampak pada kesuburan tanah.

\section{METODOLOGI PENELITIAN}

Penelitian ini dilaksanakan dengan menggunakan pendekatan penelitian pengembangan (development research). Rancangan penelitian selengkapnya dapat dilihat pada gambar 1. Dalam rancangan penelitian ini dimana media poster berbasis pendidikan karakter yang sudah valid (Lampiran 1), kemudian di- lakukan uji coba terbatas pada beberapa orang mahasiswa yang telah mengambil mata kuliah IAD yang terdiri atas mahasiswa kelompok tinggi, sedang dan rendah. Uji coba dilakukan untuk melihat kepraktisan atau keterpakaian media poster berbasis pendidikan karakter oleh mahasiswa. Adapun komponen yang akan diteliti dapat dilihat pada Tabel 1 dan format angket respon terdapat pada Lampiran 2 . Hasil uji coba tersebut dianalisis dan dilihat apakah media poster yang sudah valid telah praktis. Jika sudah belum praktis maka dilakukan revisi, sampai akhirnya diperoleh media poster berbasis pendidikan karakter yang praktis.

Lembar validasi angket respon bertujuan untuk mengetahui apakah angket yang dirancang valid atau tidak. Setelah diperoleh angket respon yang valid, kemudian angket tersebut diuji cobakan terbatas kepada mahasiswa MPI yang mengambil mata kuliah IAD. Pengisian angket menggunakan skala likert dengan range A sampai D. Angket terdiri dari 3 indikator yaitu isi, desain dan bahasa. 


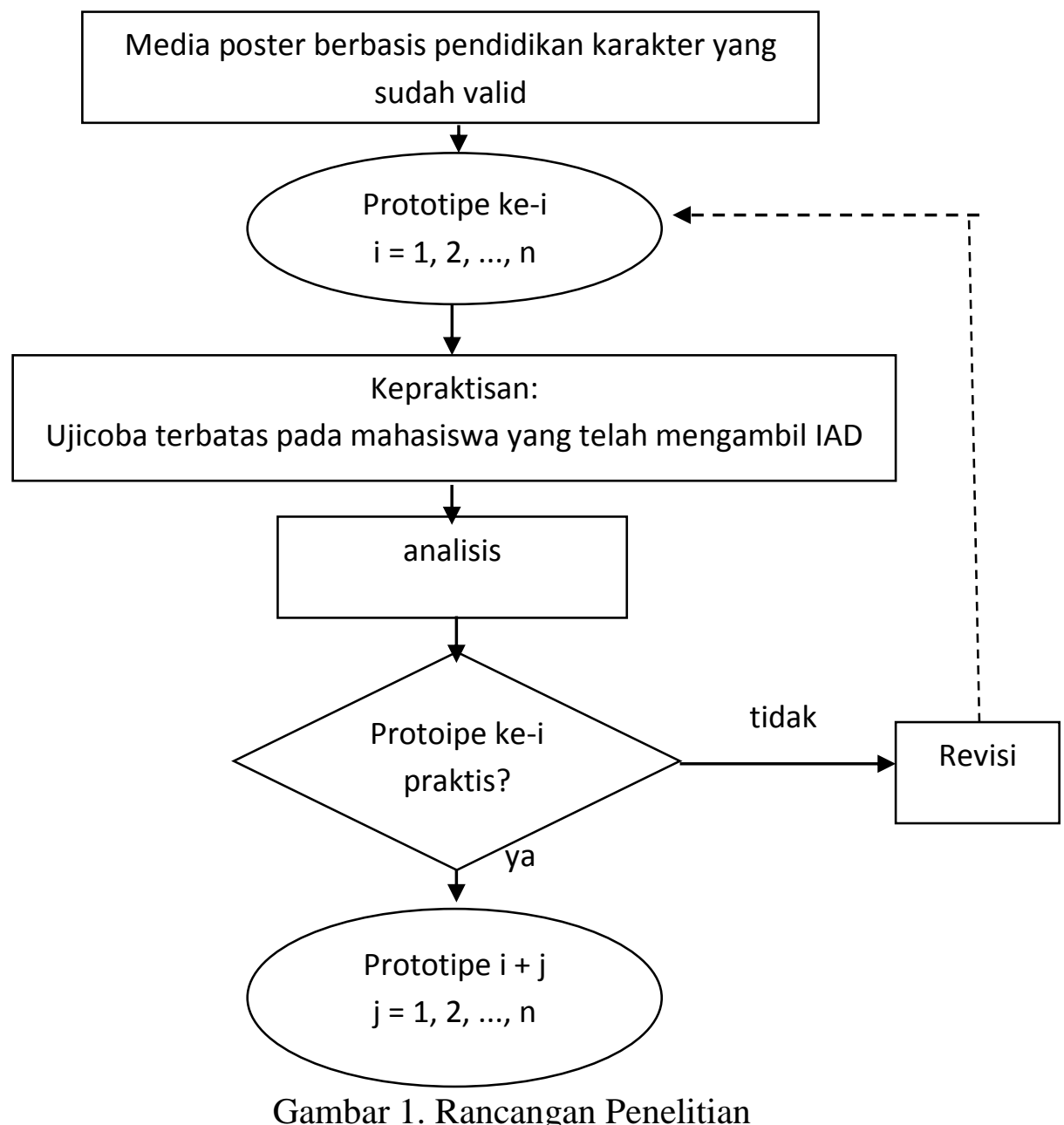

Tabel 1. Angket respon mahasiswa

\begin{tabular}{|l|l|l|l|}
\hline No & \multicolumn{1}{|c|}{ Aspek } & \multicolumn{1}{|c|}{ Metode Pengumpulan Data } & Instrumen \\
\hline 1 & Isi & $\begin{array}{l}\text { Mahasiswa MPI yang mengambil mata } \\
\text { kuliah IAD }\end{array}$ & $\begin{array}{l}\text { Angket } \\
\text { praktikalisasi }\end{array}$ \\
\hline 2 & Desain & & \\
\hline 3 & Bahasa & & \\
\hline
\end{tabular}

Data hasil tanggapan mahasiswa melalui angket yang terkumpul kemudian ditabulasi. Hasil tabulasi tiap tagihan dicari persentasenya dengan rumus:

$$
\begin{aligned}
& \text { Persentase } \\
& =\frac{\sum \text { skor per item }}{\text { skor maksimal }} \\
& \times 100 \%
\end{aligned}
$$

Berdasarkan hasil persentase, setiap tagihan dikategorikan seperti pada Tabel 2: 
Tabel 2. Kategori Praktikalitas Media Poster berbasis pendidikan karakter.

\begin{tabular}{|l|l|}
\hline $\mathbf{( \% )}$ & Kategori \\
\hline $0-20$ & Tidak praktis \\
\hline $21-40$ & Kurang praktis \\
\hline $41-60$ & Cukup praktis \\
\hline $61-80$ & Praktis \\
\hline $81-100$ & Sangat praktis \\
\hline
\end{tabular}

\section{HASIL PENELITIAN}

\section{Hasil Validasi Angket Respon Mahasiswa}

Untuk melihat respon mahasiswa terhadap pelaksanaan pembelajaran dengan menggunakan media poster berbasis pendidikan karakter, peneliti memberikan angket kepada mahasiswa. Sebelum angket diberikan kepada mahasiswa, angket yang telah dirancang terlebih dahulu divalidasikan kepada validator. Hasil validasi angket dapat dilihat pada tabel 3 berikut:

Tabel 3. Data hasil validasi angket respon mahasiswa

\begin{tabular}{lllllllll}
\hline \multirow{2}{*}{ No } & Aspek yang divalidasi & \multicolumn{2}{c}{ Validator } & \multirow{2}{*}{ Jml } & $\begin{array}{l}\text { Skor } \\
\text { maks }\end{array}$ & $\%$ & Ket \\
\cline { 3 - 6 } & 1 & 2 & 3 & & & \\
\hline 1 & Format angket & 3 & 3 & 1 & 7 & 12 & 58,3 & Cukup valid \\
\hline 2 & Bahasa yang digunakan & 6 & 5 & 3 & 14 & 24 & 58,3 & Cukup valid \\
\hline 3 & Butir pernyataan angket & 6 & 6 & 2 & 14 & 24 & 58,3 & Cukup valid \\
\hline Jumlah & $\mathbf{1 5}$ & $\mathbf{1 4}$ & $\mathbf{6}$ & $\mathbf{3 5}$ & $\mathbf{6 0}$ & $\mathbf{5 8 , 3}$ & Cukup valid \\
\hline
\end{tabular}

Berdasarkan tabel di atas dapat dikatakan bahwa format angket, bahasa yang digunakan dan butir pernyataan angket cukup valid. Sesuai dengan saran validator, dilakukan revisi terhadap angket respon, perubahan yang dilakukan sesuai saran yang diberikan validator adalah bahasa yang digunakan dan butir pernyataan angket.

\section{Hasil praktikalitas Media Poster berbasis pendidikan Karakter}

Untuk melihat praktikalitas media poster berbasis pendidikan karakter ini, dilakukan uji coba terbatas pada mahasiswa MPI semester 1 tahun ajaran 2012/2013. Uji coba terbatas media poster berbasis pendidikan karakter ini dilakukan pada akhir pertemuan. Data tentang praktikalitas media poster yang telah dirancang diperoleh dari angket respon mahasiswa. Secara garis besar hasil respon mahasiswa dapat dilihat pada tabel 4 berikut: 
Tabel 4. Data hasil praktikalitas angket respon mahasiswa

\begin{tabular}{llllll}
\hline No & Indikator angket & Skor mahasiswa & Skor maks & $\%$ & Ket \\
\hline 1 & Isi & 530 & 624 & 84,9 & Sangat praktis \\
\hline 2 & Desain & 168 & 208 & 80,7 & praktis \\
\hline 3 & Bahasa & 154 & 208 & 74 & Praktis \\
\hline Jumlah & $\mathbf{8 5 2}$ & $\mathbf{1 0 4 0}$ & $\mathbf{8 1 , 9}$ & Sangat praktis \\
\hline
\end{tabular}

Berdasarkan tabel di atas terlihat bahwa persentase penilaian mahasiswa MPI semester 1 tahun ajaran 2012/2013 terhadap media poster berbasis pendidikan karakter berkisar antara $74 \%$ sampai $84,9 \%$. Dengan demikian media poster berbasis pendidikan karakter menurut mahasiswa sudah sangat praktis.

Berdasarkan analisis dari angket respon mahasiswa diketahui bahwa:

a. Mahasiswa mudah memahami maksud yang terkandung dalam media poster berbasis pendidikan karakter.

b. Mahasiswa dapat mengambil manfaat yang disajikan pada media poster berbasis pendidikan karakter dalam menanamkan nilai-nilai peduli terhadap lingkungan, menanamkan nilai-nilai yang membuat seseorang sadar hukum dan sadar terhadap peraturan, menanamkan nilai-nilai yang membuat seseorang bertanggung jawab dan disiplin.

c. Mahasiswa mampu memahami pernyataan dan kalimat-kalimat pada media poster.

d. Mahasiswa mampu memahami ilustrasi yang diberikan pada media poster.

Dengan demikian, pertanyaan penelitian "Bagaimanakah Media Poster berbasis pendidikan karakter untuk materi Global Warming sudah praktis?" sudah terjawab, yaitu media poster berbasis pendidikan karakter sangat praktis digunakan dalam kegiatan pembelajaran. Media poster berbasis pendidikan karakter mudah dipahami dan bermanfaat dalam menanamkan nilai-nilai karakter kepada diri mahasiswa.

Media poster berbasis pendidikan karakter merupakan media visual yang disajikan berupa gambar untuk memudahkan mahasiswa memahami materi global warming. Penggunaan media dalam proses belajar mengajar mempunyai nilai-nilai praktis sebagai berikut:

a. Media dapat mengatasi berbagai keterbatasan pengalaman yang dimiliki mahasiswa.

b. Media dapat mengatasi ruang kelas.

c. Media memungkinkan adanya interaksi langsung antara mahasiswa dengan lingkungan.

d. Media menghasilkan keseragaman pengamatan.

e. Media dapat menanamkan konsep dasar yng benar, konkrit dan realistik.

f. Media dapat membangkitkan keinginan dan minat yang baru.

g. Media dapat membangkitkan motivasi dan merangsang mahasiswa untuk belajar.

h. Media dapat memberikan pengalaman yang integral dari suatu yang konkrit sampai kepada yang abstrak.

Pada media poster berbasis pendidikan karakter disajikan materi yang sesuai dengan pengalaman mahasiswa, sehingga mahasiswa mampu memahami materi yang dijelaskan sesuai dengan pengalaman masing-masing mahasiswa. Selain itu poster menuntut mahasiswa untuk dapat menelaah gambar dan keterangan yang terdapat pada media 
sehingga pemahaman mahasiswa dapat memahami materi tersebut dan dapat mengungkapkan pemahaman mereka dengan kalimatnya sendiri.

\section{Keterbatasan Penelitian}

Penelitian ini memiliki keterbatasan, antara lain:

a. Poster hanya dilakukan ujicoba terbatas, sehingga peneliti tidak mengetahui apakah pada kegiatan yang lain dapat digunakan oleh mahasiswa atau tidak.

b. Penelitian ini hanya diujikan pada satu kelas yaitu pada kelas mahasiswa MPI semester 1, sehingga peneliti tidak mengetahui apakah pada kelas lain dapat digunakan mahasiswa atau tidak.

\section{DAFTAR RUJUKAN}

Arsyad, A. 2008. Media Pembelajaran. Jakarta: PT. Raja Grafindo Persada.

Chrisiana, W. 2005. Upaya Penerapan Pendidikan Karakter Bagi Mahasiswa. Jurnal Teknik Industri Vol. 7, No 1, hal 83-90.

Kurniasih, 2003. Perbedaan Kemampuan Menulis Puisi Dengan Menggunakan Media Poster Dan Tidak Menggunakan Media Poster Pada Siswa SLTP Kelas 1 Di SLTPN 266 Jakarta Utara.

makalahdanskripsi.blogspot.com/.. ./perbedaan kemampuan menulis pusi dengan menggunakan media poster dan tidak menggunakan media poster.

Kusuma, M.A. 2010. Penggunaan Media Poster Untuk Meningkatkan c. Penelitian ini hanya dilakukan sampai tahap praktikalitas, sehingga dampak penggunan poster berbasis pendidikan karakter bagi mahasiswa dalam kegiatan pembelajaran tidak diketahui.

\section{PENUTUP}

Berdasarkan hasil analisis data yang telah dilakukan terhadap hasil uji coba yang dilakukan terhadap mahasiswa MPI semester 1 tahun ajaran 2012/2013 di STAIN Batusangkar menunjukkan bahwa media poster berbasis pendidikan karakter telah memenuhi kriteria praktikalitas yaitu dapat dipakai dan dilaksanakan dalam proses pembelajaran

Kemampuan Menceritakan Kembali Cerita Anak Secara Lisan Pada Siswa Kelas II SDN Pulungdowo 03 Tumpang Malang. UM- Skripsi. library.um.ac.id/.../penggunaanmedia-poster-untuk-meningkatkankemampuan menceritakan kembali cerita anak.

Nikmah, K., Pamungkas, N.R., Muchlisina, A. 2010. Upaya Penanggulangan Global Warming Melalui Greevourrecom. Malang. UM-PKM GT

Prasetyo, Z.K. 2009. Melalui Pembiasaan dan Keteladanan Dalam Model Pembelajaran Sains SLH Untuk Penguatan Karakter Pemula. Seminar Nasional Pendidikan Sains. UNY. 
Qusyairi, A., Permatasari, P. H. 2009. Melawan Global Warming Dengan Praktek-Praktek Green Komputing. Jakarta. Universitas Gunadarma-PKM GT
Sugiyono, 2006. Penanggulangan Pemanasan Global Di Sektor Pengguna Energi. Jurnal Sains \& Teknologi Modifikasi Cuaca, Vol. 7, No. 2, $2006: 15-19$ 